\title{
LITURGIE PŘEDEM POSVĚCENÝCH DARŮ
}

T O MÁŠ M R ŇÁVEK

$\mathrm{K}_{\mathrm{i}}$

řestanská Pascha byla vždy korunou postní doby. Celé toto období je prodchnuto zármutkem z utrpení Páně spojeným s trýzněním těla. To bylo cestou k vytvoření velmi důmyslného systému postů a odříkání vedoucímu k ustanovení čtyřicetidenní doby postní. Ta se však ukázala jako jedinečná šance k ukončení přípravy na křest tedy katechumenátu, aby mohli být o Veliké noci katechumené osvíceni Kristem, tedy pokřtěni. Katechumeni se během tohoto období intenzivně účastnili bohoslužeb, kde jim byly vštěpovány pravdy a poklady víry církve. Vskutku jedinečnou, dnes možná z různých důvodů opomíjenou bohoslužbou byzantské tradice, která byla školou katechumenů, byla liturgie Předem posvěcených darů.

\section{Terminologie}

V římské tradici byla tato liturgie pojmenována missa praesanctificatorum - mše předem posvěcených darů. V Byzanci se jí ŕíkalo $\dot{\eta} \theta \in i ́ \alpha$

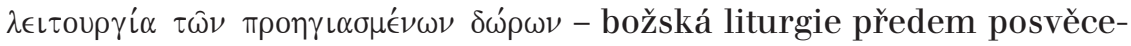

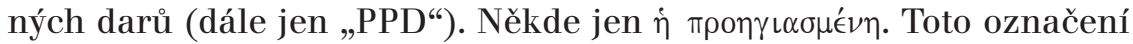
vychází ze skutečnosti, že materie k této liturgii je již posvěcena (konsekrována). Předem posvěcené dary jsou již posvěceny z předchozí liturgie a jsou během této liturgie přijímány.

Syrská liturgie užívá díl posvěceného chleba k „označeni““ (consignatio) kalichu s vínem a celý obřad se nazývá „označení kalichu“. V maronitských a jakobitských (syro-západních) misálech je pak pojmenován: ordo vel anaphora consignationis calicis. ${ }^{1}$

1 HANSSENS, Jean-M. Institutiones liturgicae de ritibus orientalibus, De missa rituum orientalium. 2. sv. Roma, 1930, č. 43, s. 23. 


\section{Definice}

V prvotní liturgii se přijímalo po lámání chleba (fractio panis). Liturgie PPD není vlastně nic jiného než slavnostní přijímání, které bylo doprovázeno různými modlitbami a rituály jako eucharistická liturgie. S výjimkou těch modliteb, které předcházejí a následují po proměňování. Po ofertoriu, tedy přinesení těchto darů na oltář, následuje Modlitba Páně. ${ }^{2}$

\section{Původ}

Někteří se domnívají, že pochází od apoštolů, patriarcha Sofronios z Jeruzaléma († 638) ji připisuje sv. Jakubovi bratru Páně, sv. Petru nebo dalším apoštolům ${ }^{3}$ a to hlavně proto, aby se podtrhla starobylost a vážnost samotného obřadu. Patriarcha Michael Kerularios (1043-1059) ${ }^{4}$ a Simeon Soluňský $(† 1429)^{5}$ hledají původ u apoštolů, nebot tato liturgie se slaví pouze $\mathbf{v}$ postní době, a ta byla ustanovena apoštoly. Někdo se domníval, že jistou indikací je Didaché IX. kapitola, kde se vyskytuje

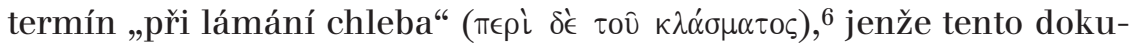
ment je př́liš raný (konec 1. století), než aby se z něho daly vyvozovat zásadní informace.

\section{Přijímání mimo liturgii}

Již od počátku církve bylo přijímání vždy spojováno se slavením eucharistie a přijímal jak celebrant tak přítomní věřící. Velmi záhy se však přijímání podává mimo slavení eucharistie. Zejména se tak postupovalo v případě nepřítomných, ${ }^{7}$ nemocných, umírajících nebo

2 BRIGHTMAN, Frank E. Liturgies Eastern and Western. Oxford, 1896, s. 586.

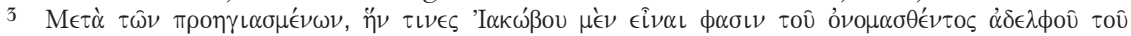

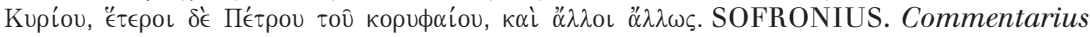
liturgicus (PG 87, 3981D).

4 LEO ALLATIUS († 1669). De Ecclesiae occidentalis atque orientalis perpetua consensione, Libri tres: Ejusdem dissertationes, De dominicis et hebdomadibus Graecorum, et de missa praesanctificatorum. Cum Bartoldi Hihusii ad hanc Annotationibus, de Communione Orientalium sub specie unica. Cologne, 1648, s. 1572-1573.

5 SIMEON SOLUŇSKÝ. Responsa ad Gabrielem Pentapolitanum, kap. 55. PG 155, 904A-C.

6 Didaché. Dottrina dei Dodici Apostoli, Simona Cives e Francesca Moscatelli (ed.). Milano: San Paolo Edizini, 2003, s. 56; KUNETKA, František. Eucharistie v křestanské antice. Olomouc: Univerzita Palackého, 2004, s. 132.

7 O donášení eucharistie nepřítomným nás informuje mučedník Justin († 165) ve své Apologii I, 67. kapitole, srov. KUNETKA, František. Eucharistie, s. 165. 
uvězněných pro víru. Tito věřící měli oprávněný nárok na tělo Páně. Roznášeli je pak dobrovolníci nebo jáhnové, ${ }^{8}$ a to $\mathrm{z}$ důvodů delšího odloučení od účasti na slavení eucharistie - Tělu Páně, což by se rovnalo hříchu. Dủležitým aspektem byla také vzdálenost, kdy se někteří nemohli dostavit na bohoslužbu. Dalším důvodem bylo nebezpečí znesvěcení a nemožnost účasti na pravověrné eucharistii. Dorotheos, soluňský biskup, v roce 519 rozdává z tohoto důvodu eucharistii v koších: Canistra plena omnibus erogarent, ne imminente persecutione communicare non possent. ${ }^{9}$

Toto soukromé přijímání bylo udržováno zejména $\mathrm{v}$ klášterech i po roce 313 (svoboda církve), které často neměly kněze. Do vzdálených vesnických farností, které neměly kněze, byli posíláni kněží a jáhni s eucharistií po biskupské bohoslužbě v katedrále.

Na počátku se eucharistická rezerva uchovávala pod obojí způsobou. Později se posvěcený chléb pokropil krví a potom před přijímáním byl vložen do kalichu s vínem, aby se zachovalo přijímání pod obojí.

Přijímání v soukromých domech se konalo analogicky k přijímání PPD samozřejmě ve skromnější podobě. Celé přijímání bylo doprovázeno více méně rozvinutým ceremoniálem, a PPD tedy byla vlastně slavnostní formou soukromého přijímání. ${ }^{10} \mathrm{~V}$ prríběhu umírajícího starce Serapiona, který přijímá in extremis, ${ }^{11}$ vystupuje chlapec, který přináší eucharistii od kněze a namočí ji v tekutině. ${ }^{12}$ Zřejmě se jednalo o víno nebo vodu. Obřad pak je více rozvinutý v příběhu o Marii Egyptské ze 7. století, která žádá přijímání nebo spíše viatikum na Velký čtvrtek. Jistý mnich Zósimás vzal tělo a krev Páně a šel k světici. „A když... nadešel den večeře Páně, udělal to, co mu žena přikázala. Vzal do malého pohárku nejčistší tělo a ctihodnou krev Pána našeho Ježíše Krista... Žena pak poprosila, aby se pomodlil vyznání víry a ,Otče náš, jenž jsi na nebesích' (Mt 6,9). A když Zósimás modlení skončil, podle obyčeje políbila starcova ústa. Když pak oba přijali životodárnou svátost..."13 Je tu zmínka o večerní mši na Velký čtvrtek. Již

\footnotetext{
8 Srov. tamtéż.

9 DUCHESNE, Louis. Origines du culte chretien, Paris: Boccard, 1920, s. 263 ; PL 63, 482.

10 Srov. tamtéž.

11 EUSEBIUS z Cesareje († 339), Historia Ecclesiastica, VI, 44, 4-5. PG 20, 632A-633A.

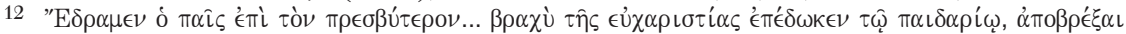

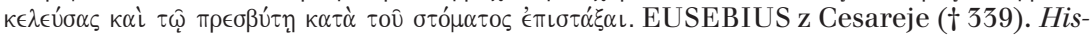
toria Ecclesiastica, VI, 44, 4. PG 20, 632A-633A.

13 Život Marie Egyptské, někdejší nevěstky, konající př́ísné pokání v Jordánské poušti. Byzantské legendy. Výbér textů ze IV.-XII. stoleti. Podle edice Vizantijskije legendy...
} 
od té doby ji bylo zvykem na východě slavit. Večerní mše se slaví i před některými velkými svátky (např. Narození Páně, Zjevení Páně).

\section{Přijímání mnichů}

Jednou z teorií je, že se PPD vyvinula z přijímání mnichů v klášterech a především ve společenstvích eremitů, poustevníků, protože jejich členové většinou nebyli kněžími. Bar Hebraeus († 1286) ve svém Nomokánonu, cituje dva kánony Jakuba z Edesy († asi 708/709): Non decet ut stylitae offerant oblationem super columnis suis. Indecens est ut inclusi offerant oblationem, nisi ob necessitatem. Neque rursus fas est, ut ponatur sanctum corpus apud stylitas supra columnam si adest eis communionem porrigat. ${ }^{14}$ Zejména se to týkalo stylitů a zatvorníků (inclusi). Bylo jim zakázáno, aby pokládali eucharistii na sloupy. Zatvorníci neměli prinášet obét' (offerant oblationem), leda z vážného důvodu.

Sv. Basil († 379) uvádí, že je zvykem v klášterech přijímat čtyřikrát týdně a to $\mathrm{v}$ neděli, středu, pátek a sobotu. Navíc pak ve sváteční dny. Posvěcený chléb v době pronásledování a v nepřítomnosti kněze a jáhna přijímali na ruku. Činí tak totiž všichni mniši eremiti, kteří nemají kněze a eucharistii uchovávají ve svých domech a sami ji přijímají. ${ }^{15}$

Theodor Studita $(† 826)$ však tuto praxi zavrhuje ve své odpovědi na otázku, zda je možné, aby mniši a mnišky si sami mohli podat

z řeckých originálů přeložili a komentářem opatřili Emilie Bláhová, [... et al.]. Doslov S. V. Poljakovové z ruštiny přeložil Václav Konzal, Červený Kostelec: Pavel Mervart,

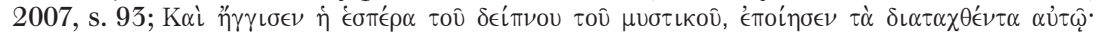

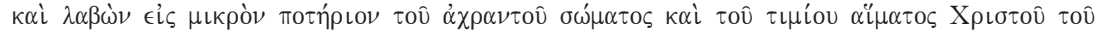

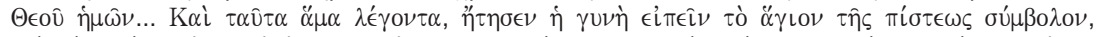

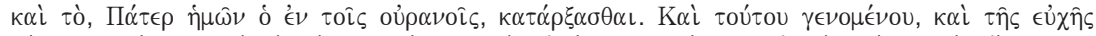

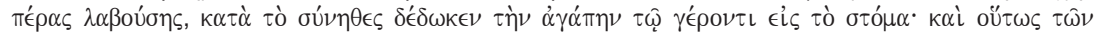

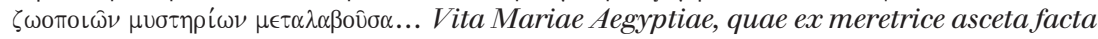
est in solitudine Jordanis. PG 87, 3721A, C.

14 Ecclesiae Antiochenae Syrorum Nomocanon a Gregorio Abulpharagio Bar-Hebreo syriacae compositus et Iosepho Aloysio Assemano in Latinam linguam conversus, kap. VII. De ordinibus sacerdotalibus, X. De coetu monachorum: Mai, Angelo. Scriptorum veterum nova collectio, 10. sv., 2. část. Rome, 1838, s. 58.

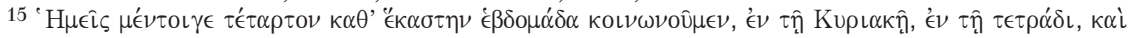

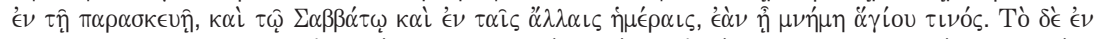

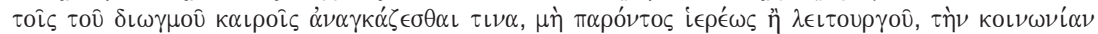

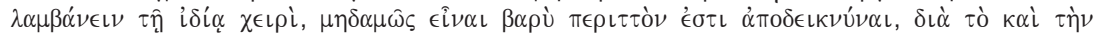

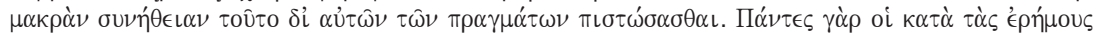

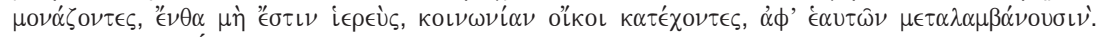
BASIL VELIKÝ. Epistola XCIII. PG 32, 484B-485A. 
eucharistii. A tvrdí, kdo není účasten kněžství, nesmí se dotýkat posvátných způsob ani z vážné příčiny. Může tak činit pouze kněz a jáhen. Postupovalo se takto, nejdříve byl rozložen na knize Písma lněný ubrousek nebo posvátné vélum a na tento provizorní oltář se položila eucharistie. Po zpěvu příslušných hymnů bylo přijímání, po němž se ústa vyplachovala vínem. ${ }^{16}$ Zvyk vyplachovat ústa vínem po přijímání se i dnes praktikuje zejména u pravoslavných. Důvodem je zabránit znesvěcení přijaté svátosti.

Jednalo se zřejmě o slavnostnější formou soukromého přijímání. Tomuto přijímání vždy předcházela modlitba Otče nás. ${ }^{17}$

Inocenc I. († 417), když píše Decenciovi z Gubia, zdůrazňuje, že mše, jakožto okamžik radosti se neslaví v postě a to zejména ve dnech bidua tedy Velkého pátku a Bílé soboty: ut traditio Ecclesiae habeat isto biduo sacramenta penitus non celebrari. ${ }^{18}$

V Alexandrii se pak neslavila liturgie ve středu a pátek, zpívaly se pouze hymny a učitelé vykládali příslušná čtení a konalo se vše ostatní, co se týkalo bohoslužby, kromě konsekrace. Tento zvyk byl starodávný a údajně sahal až k Origénovi. ${ }^{19}$ Zřejmě se při této bohoslužbě podávalo i přijímání.

\section{Liturgie předem posvěcených darů, zvláštní obřady}

Jestliže někteří hledali původ PPD ve způsobech podávání přijímání, jiní ji nacházejí v uspořádání druhé mše slavené ve 4. století v Jeruzalémě na večer Velkého čtvrtku. Tuto liturgii následuje všeobecné přijímání věřících, které se děje výjimečně jednou za rok ve svatyni Svatého křiže, post Crucem. Poutnice mniška Egerie ji popisuje takto:

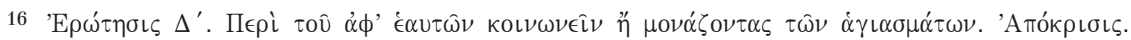

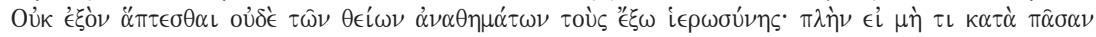

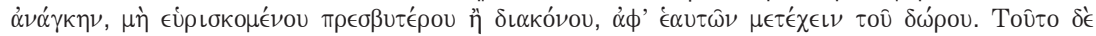

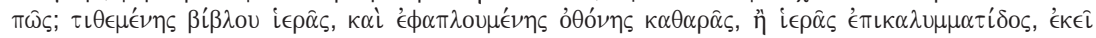

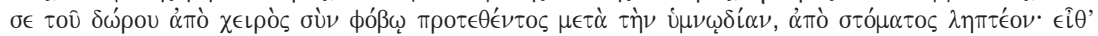

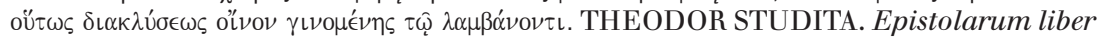
II, Epistola CCIX, $\$ 4$. PG 99, 1661B.

17 Didaché, s. 54.

18 INNOCENC I., Epistola, XXXV, Ad Decentium, kap. IV, č. 7. PL 20, 555-556.

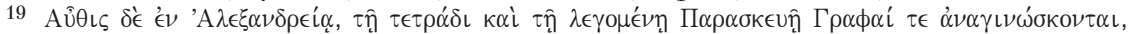

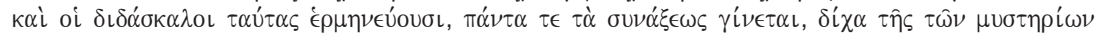

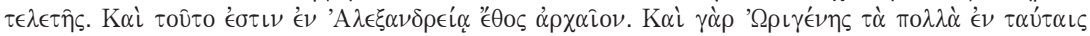

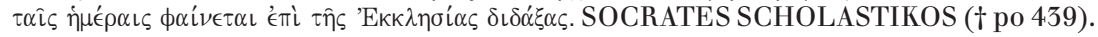
Historia ecclesiastica, liber V, kap. XXII, PG 67, 636A-B. 
„Po skončení pobožnosti v Martyriu se jde za Kříž, zde se odříká pouze jeden hymnus, vykoná se modlitba a biskup přináší obět a všichni jdou k přijímání. S výjimkou tohoto jednoho dne se po celý rok nikdy neobětuje za Křížem, pouze v tento jediný den.“20

Tato večerní mše na Velký čtvrtek v Jeruzalémě i jinde byla slavena jako památka na ustanovení eucharistie, jak o tom hovoří 29. kánon Kartaginského koncilu (397) ${ }^{21}$ nebo sv. Augustin. ${ }^{22}$ Všichni věřící před tím, než přistoupili k přijímání, pojedli, jako apoštolové při poslední večeři. Později bylo všeobecné přijímání přesunuto na Velký pátek jak to například pro 8. století pro Řím dosvědčuje Ordo Romanus I., kdy se kněží po 15. hodině shromáždili v kostele k přečtení evangelia, velkopátečním přímluvám a adorování křiže, po kterém všichni přistupovali k přijímání. ${ }^{23}$

Mohlo by se říci, že mše nemohla být slavena ve dnech postu z důvodu smutku, a to především na Velký pátek. Tyto dva aspekty radosti a smutku nebylo vhodné slučovat. Věřící však stejně nechtěli zůstat bez přijímání ani v tyto dny. Pomalu se ze soukromého přijímání vyvinula liturgie PPD, která měla strukturu mešní liturgie.

\section{První konkrétní svědectví}

Patriarcha Severus z Antiochie (511-518) z pastorační horlivosti povoluje přijímat častěji než ve mši v neděli, a to zejména v postní dny, kdy se neslaví liturgie. Posvěcený chléb má být při nedělní mši namočen do posvěcené krve a pak uchován ve zvláštní nádobě, protože víno není možné uchovávat. Potom při přijímání v jiné dny má být tímto chlebem označen kalich s vínem, aby se udržela pravověrná

20 Itinerarium Egeriae. Putování Egeriino, č. 35, Text, překlad a komentář Marcela HEJTMANOVÂ, České Budějovice: Jihočeská univerzita, 1999, s. 135; Facta ergo missa Martyrii uenitur post Crucem, dicitur ibi unus ymnus tantum, fit oratio et offeret episcopus ibi oblationem et communicant omnes. Excepta enim ipsa die una per totum annum nunquam offeritur post Crucem nisi ipsa die tantum. Itinerarium Egeriae, č. 35, in MARAVAL, P. (ed.), Egérie. Journal de Voyage (Itinéraire), Sources Chrétiennes 296, Paris: Cerf, 1982, s. 278-280.

21 „Ut sacramenta altaris non nisi a jejunis hominibus celebrentur, excepto uno die anniversario, quo coena Domini celebratur“. THIBAUT, J.-B. Origine de la messe des présanctifiés, Echos d'Orient, 20 (1920), s. 38 a pozn. 1.

22 AUGUSTINUS AURELIUS. Epistola 55. Ad inquisitiones Januarii, kap. I. PL 33, 204.

23 Deinde revertentur presbiteri per titula sua, et hora nona tam de lectionibus quam responsoriis vel evangelium seu et oraciones sollemnes faciunt similiter, et adorant sanctam crucem et communicantur omnes. DUCHESNE, Louis. Origines, s. 488. 
tradice přijímání pod obojí. ${ }^{24}$ Určité předpisy o označování kalicha nám zanechává Jan z Telly († 538). ${ }^{25}$ Jedná se o soubor otázek kněze Sergia a Janových odpovědí: Discipulus interrogat: An fas est ut margaritam, qua calix consignatus est, sumat alius, praeter eum, qui calicem consignavit? Magister (respondet): Margaritam, qua calix consignatur, quoties minister calicem ministrat, toties sumat; nec de illa re mandatum aliquod invenimus. ${ }^{26}$... Si quis oblationem sumpserit calicemque ministraverit, an, urgente necessitate, calicem postea consignare potest?... Si calicem tantum ministraverit, et postea necessarium sit calicem consignare, fidelis est Deus, ut absque culpa sit; sed hoc ad consuetudinem non fiat. ${ }^{27}$

Přesnější informace uvádí Chronicon paschale (615), podle kterého se PPD začíná slavit v první týden velkého postu. I když hymny a zpěvy, které doprovázejí tuto liturgii, se užívají i mimo dobu postní. Zmiňuje

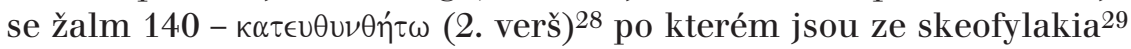

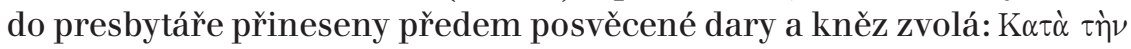

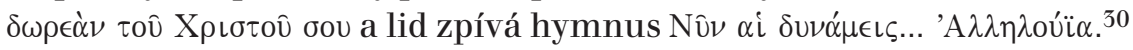

\section{Vyjádření koncilů}

Koncil v Laodicei (4. století) v kán. 25 zakazuje podjáhnům podávat chléb a žehnat kalich. ${ }^{31}$ Zřejmě se mohlo jednat již o zmíněné consignatio calicis. ${ }^{32}$ Kánon 49 . téhož koncilu zakazuje slavit liturgii

24 ANDRIEU, Michel. Immixtio et consecratio, la consécration par contact dans les documents liturgiques du Moyen Age. Paris, 1924, s. 229.

25 Joannis Telae resolutiones canonicae. In: LAMY, Thomas-J. Dissertatio de Syrorum fide et disciplina in re eucharistica. Louvain: Vanlinthout, 1859, s. 71-79.

26 Tamtéž, s. 71.

27 Tamtéž, s. 77.

28 „Má modlitba at́ je před tebou jako kadidlo.“

29 Místnost nebo budova, kde mohly být uchovávány liturgické nádoby a bohoslužebné knihy. Skeuofylakion katedrály Hagia Sofia v Konstantinopoli (Istanbul), v době Jana Zlatoústého, to je na konci 4. století, bylo umístěno mimo kostel, za apsidu. TAFT, Robert F. Stručné déjiny byzantské liturgie. Velehrad-Roma: Refugium, 2011, s. 83-84.

30 PG 92, 989A-B; TAFT, Robert F. The Great Entrance. A History of the Transfer of Gifts and Other Preanaphoral Rites of the Liturgy of St. John Chrysostom, Orientalia Christiana Analecta 200. Roma, 2004, s. 76.

31 "O pline générale antique. Les canons des synodes particuliers (IVe-IX ${ }^{\mathrm{e}}$ siècles), 1/2. sv. Grottaferrata, 1962, s. 141.

32 HÉFÉLÉ, Charles-J. Histoire des conciles d'après les documents originaux, 1. sv. Paris: Letouzey et Ane, 1907, s. 1013. 
v postní době, kromě neděle a soboty, ${ }^{33}$ které jsou v byzantské tradici plně liturgické, tedy se má slavit mešní liturgie. Možná se zde naráží na PPD, které se slaví ve všední dny. Kánon 51. zakazuje slavit památky svatých mučedníků, kromě soboty a neděle, nebot' svátky jsou úzce vázány na liturgii. ${ }^{34}$ Dále pak Trulánský koncil (692), kánon 52: po všechny dny posvátné doby postní, kromě sobot, nedělí a Zvěstování (25. března) se slaví liturgie PPD. ${ }^{35}$

Pokud jde o zmíněné Consignatio calicis patriarcha Severus pouze zveřejnil soukromou praxi označení kalicha. Původ je tedy v Sýrii a tato zvyklost přešla do Byzance. To je zřejmě podmíněno i tím, že území Byzance bylo pod církevním vlivem Antiochie až do přelomu 5. století, protože byla největším centrem liturgického dění prefektury Oriens. Není nutné zmiňovat nejvýznamnější osobnost, Jana Zlatoústého, který byl knězem v Antiochii před tím, než se stal v roce 398 biskupem v Konstantinopoli. ${ }^{36}$

\section{Byzanc}

PPD se v byzantských církvích běžně slouží v postní době jak u katolíků (méně), tak u pravoslavných. Plná liturgie, mše, by se měla sloužit pouze v sobotu, neděli a na významné svátky. V ostatní dny, tzv. aliturgické dny, by se neměla sloužit žádná liturgie nebo jen PPD, jak to předepisují liturgické knihy. ${ }^{37}$ Byzantský obřad slaví PPD nejčastěji ze všech východních obřadů. Jádro obřadu se nachází již v nejstarším řeckém rukopisu Barberinianus graecus č. 336 z 8. století, který byl

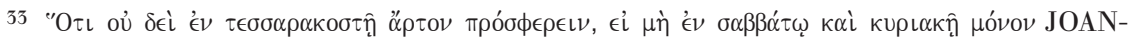
NOU, Périclès-P. Discipline générale antique, s. 150.

34 "O

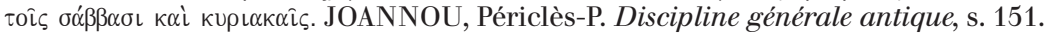

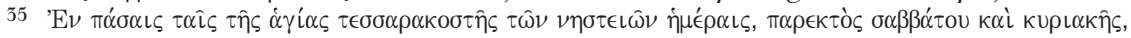

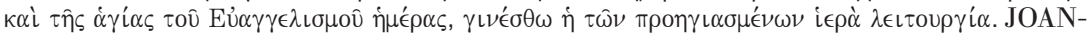
NOU, Périclès-P. Discipline générale antique, s. 189.

36 TAFT, Robert F. Stručné dějiny, s. 19.

37 Srov. Codex Canonum Ecclesiarum Orientalium, kán. 704: „Divina Liturgia omnibus diebus laudabiliter celebrari potest exceptis eis, qui secundum praescripta librorum liturgicorum Ecclesiae sui iuris, cui sacerdos ascriptus est, excluduntur.; Srov. KONGREGÁCIA PRE VÝCHODNÉ CÍRKVI. Inštrukcia na aplikáciu bohoslužobných predpisov Kódexu kánonov východných cirkvi, č. 63, http://www.grkat.nfo .sk/Texty/instrukcia_8.html\#63.\%20Takzvan $\%$ C3\%A9\%20\%E2\%80\%9Caliturgick \%C3\%A9\%E2\%80\%9D\%20dni (12. 1. 2012). 
napsán v Jižní Itálii v Kalábrii. ${ }^{38}$ Autorství PPD je různé: Sofronios († 638) ji připisuje sv. Jakubu a sv. Petru, ${ }^{39}$ jiní pak sv. Marku, evangelistovi, ${ }^{40}$ sv. Basilu († 379), sv. Germanovi († 733), sv. Epifaniovi ze Salaminy († 403), ${ }^{41} \mathrm{sv}$. Atanášovi $(† 373) .{ }^{42} \mathrm{~V}$ současnosti převládá mínění, že autorem je papež Řehoř Veliký (†604). Jeho jméno figuruje v názvu této liturgie, jako např́klad: „La Divine liturgie de notre saint père Grégoire le Grand ou des présanctifiés“.43 Thibaut se domnívá, že to je právě tento papež, nebot' on zavedl modlitbu Otče náš do závěru římské liturgie a tato modlitba je i na konci liturgie PPD před přijímáním. ${ }^{44}$

\section{Povaha Liturgie předem posvěcených darů a intence (mešní stipendium)}

Jistý teologický problém vyvstane, když se podrobněji podíváme na tuto liturgii. Jde o to, zda se jedná o skutečnou obět' (sacrificium). Katolická nauka má pouze jedinou odpověd': podstatou oběti je konsekrace. Konsekrace je podstatnou součástí mše a je zakázáno konsekrovat mimo ni. ${ }^{45} \mathrm{~V}$ Byzanci tento problém vyvstal, pokud šlo o intenci (mešní stipendium) za liturgii. Tedy, může kněz dostat stipendium za tuto liturgii? Melchitský synod na hoře Libanon v Carcafé (1806), kán. 13, č. 3, tuto praxi uznává, protože tomuto obřadu neschází nic, aby to mohlo být pravé sacrificium: podání (oblatio) a dovršení (consummatio). Z toho plyne, že plody vykoupení jsou připočitatelné, tedy lze přijmout stipendium za tuto bohoslužbu. ${ }^{46}$

38 PARENTI, Stefano - VELKOVSKA, Elena. L'Eucologio Barberini gr. 336. Roma: CLV - Edizioni Liturgiche, 2000, folia 37v-43v, 257r-262r, s. 83-87, 245-247. Parenti má chybné číslování folií, začíná PPD foliem 38v, přičemž má být 37v; ARRANZ, Miguel. L'Eucologio Costantinopolitano agli inizi del secolo XI. Hagiasmatarion \& Archieratikon (Rituale \& Pontificale) con l'aggiunta del Leiturgikon (Messale). Roma: Editrice Pontificia Università Gregoriana, 1996, s. 579-585.

39 Viz výše: Původ.

40 TREMPELAS, Panagiōtēs N. Hai treis leitourgiai : kata tous en Athênais kôdikas (=Texte und Forschungen zur byzantinisch-neugriechischen Philologie, 15). Athênai, 1935, s. 195.

41 PITRA, Jean B. Iuris Ecclesiastici Graecorum Historia et Monumenta. 2. sv. Roma, 1868, s. 296, poz. 6, 321, poz. 5; BRIGHTMAN, Frank E. Liturgies Eastern, s. XCIII.

42 LEBRUN,Pierre. Explication desprières et des cérémonies delamesse.2.sv.Paris,1726, s.376.

43 CHARRON, Cyrille. Les saintes et divines liturgies de l'église grecque catholique orientale. Beyrouth, 1903, s. 103.

44 ŘEHOŘ VELIKÝ. Epistola IX, 12. Srov. THIBAUT, J.-B. Origine de la messe, s. 42.

45 Kodex kanonického práva (Codex Iuris Canonici), Praha: Zvon 1994, kán. 927.

46 Permettiamo ai sacerdoti che adempiono questa liturgia di prendere senza diminuzione la elemosina solita darsi a quelli che offrono la liturgia del Crisostomo. Non vi è 
V roce 1835 papež Řehoř XVI. († 1846) tento koncil zavrhuje. ${ }^{47}$ O měsíc později jej melchitský patriarcha Maximus Mazlum také zavrhuje. ${ }^{48}$ Ve stejném roce se koná synod v Ain-Traz (Libanon), kde kán. 3. dovoluje kněžím přijmout stipendium za PPD. Staví ji na roveň ostatním bohoslužbám a obřadům za zemřelé. Důvodem je, che contiene qualche cosa essenziale di ciò, che è essenziale nell'intera messa, e con ragione si stima cosa buona offrirla a Dio per vivi e per i morti. 49

V roce 1849 patriarcha Mazlum schvaluje zavrženou praxi na synodu v Jeruzalémě a dovoluje přijímat stipendium za PPD. ${ }^{50}$ Apoštolský stolec však zavrhuje i tento synod. Nový synod v roce 1909 obhajuje tuto praxi, pokud souhlasí dárce: haec missa enim non est sacrificium sed oblatio; sacrificium autem in praecedenti missa fuit perfectum. ${ }^{51}$

Řeckokatoličtí Rusíni obhajují praxi nepřijímání honoráře za PPD. ${ }^{52}$ Řeckokatoličtí Rumuni pak v Alba Julii v roce 1900 prohlásili, že se nejedná o obět, čili nelze přijmout stipendium jako při liturgii sv. Basila nebo sv. Jana Zlatoústého. ${ }^{53}$

\section{Den kdy se slaví PPD}

Trulánský koncil (692) ve svém 52. kánonu předepisuje slavení PPD po všechny dny doby postní kromě sobot a nedělí a slavnosti

motivo a qualunque onde reputi estraneo l'aver nel stabilito di prendere la elemosina per la offerta di questa liturgia, poiché se col permesso dei superiori si è introdotta la consuetudine de prendere una quantità di elemosine per la offerta di alcune preci, come sarebbero le requie ed i funerali e li paradisi ed altre, con maggior ragione conviene che si determini una elemosina per la offerta di questa rispettabilissima ed oltremodo vantaggiosa liturgia, massimamente perché contiene in se l'essenza dell'incruento sacrificio, che consiste in modo speciale nell'oblazione e nella sagramentale consacrazione. In essa altresì si offre alla santissima Trinità il corpo ed il sangue dello stesso nostro signor Gesù Cristo e viene portato processionalmente con solennità e devotissime preci, ed inoltre si fa la consumazione del sacrificio per mezza della comunione. Nulla dunque vi manca di essenziale alla liturgia della presantificazione, cade sia sacrificio compito, che ottiene tutti i frutti e le grazie determinate dal nostro redentore Gesù Cristo a coloro che offrono l'incruento sacrificio. MANSI, Joannes D. Sacrorum conciliorum nova et amplissima collectio, 46. sv. Paris, 1911, s. 739B-D.

47 Tamtéž, s. 875.

48 Tamtéž, s. 973.

49 Tamtéž, s. 985D.

50 Tamtéž, s. 1033D.

51 HANSSENS, Jean-M. Institutiones liturgicae, s. 110.

52 Acta et decreta synodi Ruthenorum Leopolensis anno 1891 habitae. Rome, 1896, s. 42.

53 Concilium provinciale tertium provinciae ecclesiasticae graeco-catholicae Alba-Juliensis et Fogarasiensis celebratum, Alba-Julia, 1900, s. 98, 99-101. 
Zvěstování (25. března) ${ }^{54}$ a Chronicon Paschale předpokládá, že je možné slavit PPD také kromě doby postní. ${ }^{55}$ Patriarcha Niceforus (806-815) dodává, že tato liturgie se koná třikrát do týdne během postní doby a po všechny týdny roku ve středu a pátek a 14. září. ${ }^{56}$ Jistě se však jednalo o jiný obřad než dnešní PPD, který je součástí postních nešpor. Přijímání PPD se podávalo také např́iklad př̀i svatbě a královské korunovaci. ${ }^{57}$

V současnosti se slaví v postní době syropostním týdnem počínaje ve středu a pátek. Ve svatém týdnu v pondělí, úterý a středu. Dále pak při určitých příležitostech a místních zvycích na svátek Charalampa 10. února, První a druhé nalezení hlavy sv. Jana Křtitele, svátek sebatských mučedníků 9 . března a vigilii Zvěstování Páně 24 . března. ${ }^{58}$ Pokud tyto dny připadnou na sobotu nebo na neděli tak se slaví liturgie.

Slavení této liturgie v souladu se starobylou praxí, jak ji podávají koncily, je striktně zachováváno u pravoslavných, tedy se slaví ve středu a pátek doby postní. Pondělí, úterý a čtvrtek je aliturgický den. Řeckokatoličtí Rusíni s dovolením ordináře mohou slavit v tyto dny liturgii sv. Jana Zlatoústého. ${ }^{59} \mathrm{~V}$ současnosti slaví tuto liturgii až na nepatrné výjimky každý den doby postní kromě neděle, kdy se slaví liturgie sv. Basila Velikého. V řeckokatolickém apoštolském exarchátu v České republice se PPD slaví v postní době v kostele Nejsvětější Trojice (slovensky) a u sv. Kosmy a Damiána v Emauzích (česky). Řeckokatoličtí Rumuni odmítají tuto praxi, protože není možné místo PPD slavit liturgii sv. Jana Zlatoústého. ${ }^{60}$

54 Viz výše: Vyjádření koncilů.

55 PG 92, 989, viz výše: První konkrétní svědectví.

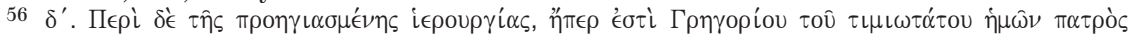

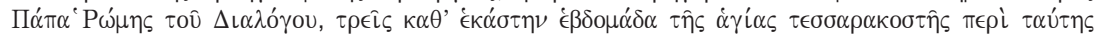

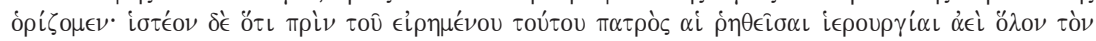

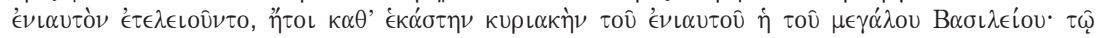

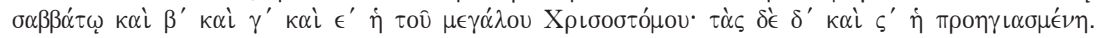

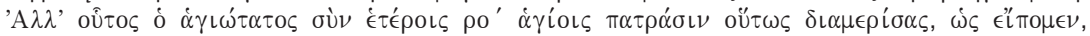

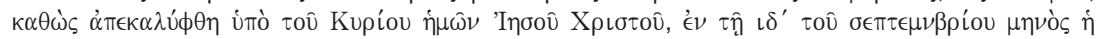

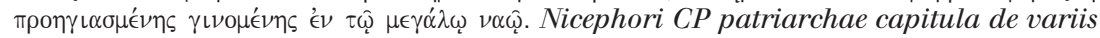
argumentis, kap. 4.: PITRA, Jean B. Iuris Ecclesiastici Graecorum, s. 321. ARRANZ, Miguel. L'Eucologio Costantinopolitano, s. 17, svatba: 326-329, korunovace: 337.

58 CHARRON, Cyrille. Les saintes et divines liturgies, s. 130. Acta et decreta synodi Ruthenorum Leopolensis anno 1891 habitae. Rome, 1896, s. 37.

60 Concilium provinciale tertium provinciae ecclesiasticae graeco-catholicae Alba-Juliensis et Fogarasiensis celebratum. Alba-Julia, 1900, s. 89. 
Téměř by se zdálo, jak bylo nastíněno, že některé východní církve nedodržovaly tuto disciplínu teprve od 19. století. K dispozici však máme přípisy Apoštolského stolce, které přikazují slavit mešní liturgii pouze v sobotu a v neděli doby postní již z roku 1695 nebo 1729, adresované melchitům v Sýrii. Podobně pak papež Benedikt XIV. v roce 1743 v encyklice Demandatum coelitus přikazuje totéž. ${ }^{61}$ Již zmíněný synod v Ain-Trazu (1835) ve 3. kánonu zakazuje sloužit liturgii sv. Jana Zlatoústého v postní dny. Činí však výjimku s dovolením biskupa, když se jedná o chudé vesnické kostely, které nemohou důstojně uchovávat eucharistii. ${ }^{62}$ Současným stanoviskem Apoštolského stolce je zachovávat aliturgické dny dle různosti liturgických tradic východních církví a tedy pro slavení PPD, jak předepisují liturgické knihy, které jsou platnou a závaznou normou. ${ }^{63}$

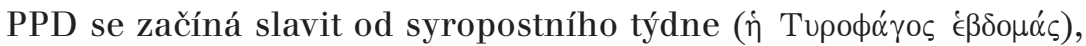
tedy týden po masopustní neděli. ${ }^{64}$ Chronicon paschale ji uvádí na první týden postní, tedy týden po syropostním týdnu. ${ }^{65}$ Patriarcha Niceforus potvrzuje středu a pátek syropostního týdne, kdy mniši mohou po PPD jíst sýr, ${ }^{66}$ dále pak středu a pátek po celý rok a 14 . záŕí. ${ }^{67}$ Jan Damašský ve svém díle De sacris ieiuniis, č. 5, umožňuje slavit PPD každý den postu, kromě sobot a nedělí a týdne xerofafie od pondělí do čtvrtka, kdy se jedly pouze suché, nevařené pokrmy, tj. $\xi_{\eta} \rho \phi \alpha \gamma i \alpha,{ }^{68}$ odpovídá našemu svatému týdnu. Podle jiných pramenů, například Kanonarion z Jeruzaléma (7. století), se uvádí pouze Velký pátek, kdy se slavily PPD. ${ }^{69}$ Typikon Velkého kostela, katedrály Svaté Moudrosti v Konstantinopoli z 10. století předepisuje PPD od syropostní středy ${ }^{70}$ každý všední den po celou dobu postní a také na Velký pátek. ${ }^{71}$

61 Benedicti XIV. papae Bullarium, 1. svazek, 2. díl, s. 148-161, zvláště s. 154.

62 MANSI, Joannes D. Sacrorum conciliorum, s. 740, 985-986.

63 Viz poz. 37.

64 SIMENOS SOLUŇSKÝ. Responsa ad Gabrielem Pentapolitanum. (PG 155, 904-912); LEO ALLATIUS. De Ecclesiae occidentalis atque orientalis, s. 1595-1597.

65 PG 92, 989.

66 PITRA, Jean B. Iuris Ecclesiastici Graecorum, kán. 40, s. 331.

67 Viz výše.

68 PG 95, 69D.

69 THIBAUT, J.-B. Origine de la messe, s. 41.

70 MaTeOS, Juan. Le Typicon de la Grande Église. Ms. Sainte-Croix $n^{\circ}$. 40, Xe siècle. Introduction, texte critique, traduction et notes, 2 . sv. Orientalia Christiana Analecta 166. Roma, 1963, s. 6, 12-13; GETCHA, Job. La réform liturgique du métropolite Cyprien de Kiev. L'introduction du typikon sabate dans l'office divin. Paris, 2010, s. 263.

71 MATEOS, Juan. Le Typicon de la Grande Église, s. 82; GETCHA, Job. La réform liturgique, s. 281. 
Konstantinopol opustila slavení PPD na Velký pátek ve 12. století díky klášteru Evergetis ${ }^{72}$ a jisté svědectví podává poutník Antonín z Novgorodu, který navštívil Konstantinopol kolem roku 1200 a konstatuje, že se v tento den PPD neslaví. ${ }^{73} \mathrm{~V}$ Rusku se pak o neslavení PPD na Velký pátek zasloužil metropolita Cyprián († 1406) ve 14. století. ${ }^{74}$

\section{Hodina slavení PPD}

Východ zachovává tradici postu do tří hodin odpoledne, a tedy se ani nepřijímalo, aby se neporušil půst. ${ }^{75}$ Věhlasný liturgista Arranz zdůrazňuje, že liturgie se běžně slaví jedině v ranních hodinách a přistupuje se k přijímání. Pouze třikrát do roka se slaví liturgie o vigilii významných svátků jako Vánoce, Zjevení Páně a Pascha. Trulánský koncil (692) proto stanovil, kromě Zvěstování Páně, aby se přijímalo o PPD až po nešporách, jejichž je i dnes nedílnou součástí ve vymezené dny, aby se zajistila serióznost odříkání postní doby. ${ }^{76}$

\section{Svatostánek}

Při nedělní liturgii se připraví dostatečné množství chlebových „beránků“ (đ’uvoí), které se vykrojují stejnými úkony a modlitbami, jako beránek, který je pak rozdělován při nedělní liturgii. Avšak konsekrují se všechny najednou, protože je pouze jeden Kristus. Po přijímání je kněz lžičkou zvlhčí krví Páně v místě křížového naříznutí, aby se zdůraznila jednota těla a krve Páně ${ }^{77}$ a vloží do artoforia (svatostánku). Dbá se na to, aby pes nebo myš nesnědli tyto dary, jinak je kněz stižen trestem suspenze. ${ }^{78}$

72 ДМИТРИЕВСКИЙ, Алексей. Описание титургических рукописей храня-щихся в библиотеках православнаго Востока, 1. sv. Киев,1895, s. 553.

73 KHITROWO, Mme. B. de. Itinéraires russes en Orient. Geneva, 1889, s. 105.

74 GETCHA, Job. La réform liturgique, s. 257, 281-282.

75 Podobně NICETAS (11. století), Contra latinos, kap. XIV. PG 120, 1018-1019; SIMEON SOLUŇSKÝ. De sacra precatione, č. 352-356; Responsa ad Gabrielem Pentapolitanum, kap. 56 (PG 155, 649-661, 904).

76 ARRANZ, Miguel. La liturgie des Présanctifiés de l'ancien Euchologe byzantin. Orientalia Christiana Periodica 47 (1981), s. 388.

77 LE BRUN, Pierre. Explication des prières, s. 375.

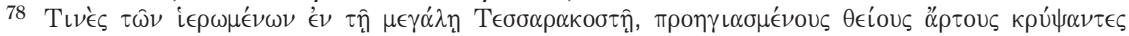

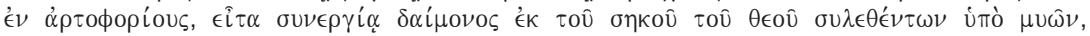

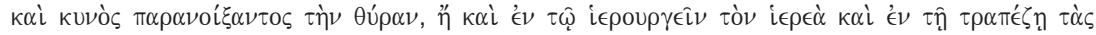

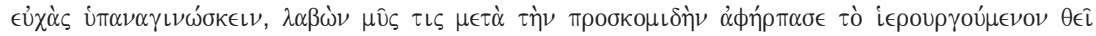


Při velkém vchodu PPD jde kněz $k$ žertveniku ${ }^{79}$ a vezme jeden z těchto beránků a kalich s vínem do kterého se přidává trochu vody. Původně se uchovávalo tělo Páně, tj. posvěcení beránci a také krev Páně, nebot text druhé modlitby věřících to předpokládá: Hle jeho nejčistši tèlo a oživujíci krev, jsou prináseny $v$ prüvodu, aby byly položeny na mystický oltár̆, doprovázeny neviditelným nebeským zástupem. ${ }^{80}$ Podobně pak modlitby před Otčenášem, před přijímáním a po přijímání se neustále zmiňují o tělu a krvi, i když krev se již neuchovává. To pramení z neměnnosti liturgických textů. Patriarcha Michael Kerularios (1043-1059) pak zakazuje namáčení. ${ }^{81}$ Ještě ve 14 . století se v Konstantinopoli beránek neoznačoval krví Páně. ${ }^{82}$

\section{Obřad - nešpory, litanie, prothesis}

Jak již bylo nastíněno liturgie PPD je dnes součástí nešpor. Začíná se recitací žalmu (Žl 103) při kterém se kněz modlí příslušné modlitby, následuje velká ektenie, kterou pronáší jáhen a je stejná jako v běžné liturgii. ${ }^{83}$

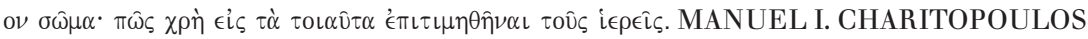
(1215-1222). Solutiones quarumdam quaestionum. 1. kap. PG 119, 809A.

79 Je to stůl, na kterém se připravuje chléb a víno k liturgii. Nachází se vlevo od oltáře, někdy v malé apsidě nebo výklenku na severní straně svatyně.

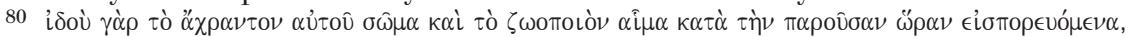

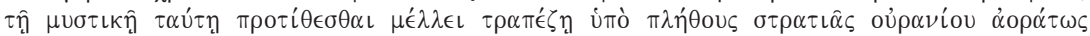

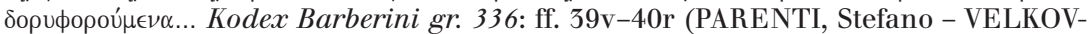
SKA, Elena. L'Eucologio Barberini gr. 336, s. 84).

ANDRIEU, Michel. Immixtio et consecratio, s. 202-206.

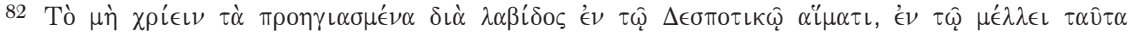

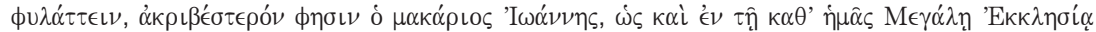
$\gamma \iota \nu$ ó $\in$ vov'. Epitome divinorum sacrorumque canonum Constantino Harmenopulo, 2. část, 6. hlava. PG 150, 97C; GOAR, Jacobus. Euvcolo,gion sive Rituale Graecorum complectens ritus et ordines Divinae Liturgiae, officiorum, sacramentorum, consecrationum, benedictionum, funerum, orationum \& c.cuilibet personae, statui, vel tempori congruos, juxta usum Orientalis Ecclesiae [...] editio secunda expurgata \& accuratior. Venice, 1730 (reprint: Graz, 1960), s. 176.

83 Liturgie začíná velkou litanií-synapte. „Synapte“ (oratio, prex, modlitba) označuje modlitbu rozdělenou do různých proseb. První prosbou je $V$ pokoji modleme se k Pánu a další dvě prosí rovněž za pokoj. V různých obřadech se mohou mezi tyto dvě prosby vkládat příslušné invokace, které se vztahují k té či oné příležitosti. Jako např́iklad svěcení křestní vody nebo při svatbě či chirotonii (svátost svěcení) atd. Tedy před předposlední všeobecnou prosbu (Za vysvobození ode všeho zármutku) se mohou vložit zvláštní prosby podle okolností. MRŇÁVEK, Tomáš. Synapte, vznik a původ tří antifon, Spev v byzantsko-slovanskej liturgii. Zbornik prednášok z vedeckej konferencie uskutočnenej v Prešove 26. marca 2009 v budove GTF PU v Prešove. Prešov, 2009, s. 160-162. 
Po ní má kněz připravit dary, tj. během 18 . kathismy, ${ }^{84}$ která je z žalmů 119-133. Během první části kathismy odloží evangelium, rozloží antimins, ${ }^{85}$ přinese ze žertveniku diskos (patenu), vyjme beránka a hluboce se ukloní. Během druhé části kathismy okuřuje beránka a s jáhnem se hluboce ukloní. Jáhen bere svíčku a obcházejí třikrát oltář a okuřuje se. Znova se pokloní. Během třetí části kathismy se přenese diskos na žertvenik a připraví se víno a voda. Okuřuje se hvězdice a malý pokrovec (vélum) a pak velký pokrovec a přikryje se kalich a diskos. Následuje prosba Na př́mluvu našich svatých otců. Pane Ježiši Kriste, Bože náš, smiluj se nad námi. Tento obřad je však bez modliteb, protože beránek je již posvěcen z nedělní liturgie. ${ }^{86}$

\section{Malý vchod}

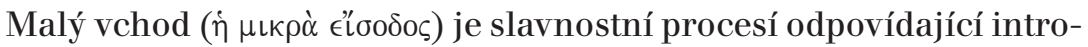
itu latinské mše, kdy jáhen nese kadidlo, kněz evangelium, pokud se čte. To se týká pouze těchto svátků, když připadnou na středu nebo pátek, kdy se slaví PPD: 24. února První a druhé nalezení hlavy sv. Jana Křtitele, 9. března Čtyřiceti sebatských mučedníků, na svátek kostela nebo první tři dny strastného (svatého) týdne. Číst evangelium při zmíněných svátcích bylo zvykem až od Simeona Soluňského. ${ }^{87}$ Při běžné

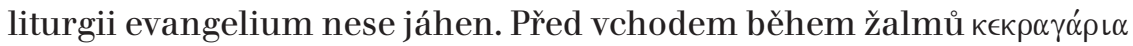
$(140,141,129,116),{ }^{88}$ přisluhující rozžíhají svíce v kostele a kněz nebo jáhen okuřuje oltář, svatyni, ikonostas a celý kostel. Během posledního verše následuje vchod, kdy první jde svíčkonosec za ním jáhen s kadidlem a pak kněz. Obcházejí oltář proti směru hodinových ručiček a vycházejí severní (levou) bránou ikonostasu z pohledu do presbytáře. Poté se zastaví před svatým, královským vchodem, který je centrálním vchodem ikonostasu a jáhen okouří ikony, kněze a říká: Požehnej,

84 Jedna z dvaceti částí, na které je rozdělen žaltář. Každá kathisma (sedalen) je rozdělena na tř̀i stasis (každá má tři žalmy). TAFT, Robert F. Stručné dějiny, s. 82.

85 Je určen $\mathrm{k}$ tomu, aby $\mathrm{v}$ př́padě pochybnosti zajistil posvěcení oltáře, a slouží i jako přenosný oltář (altare portatile). Jedná se o kus lněné nebo hedvábné látky čtvercového nebo obdélníkového tvaru. Musí být posvěcen a opatřen ostatky. MRŇÁVEK, Tomáš. Antimins, in Řeckokatolický kalendár 2008, Praha: Apoštolský exarchát Řeckokatolické církve v ČR 2008, s. 59-64.

87 SIMEON SOLUŇSKÝ. Responsa ad Gabrielem Pentapolitanum, 55. kap. PG 155, 905.

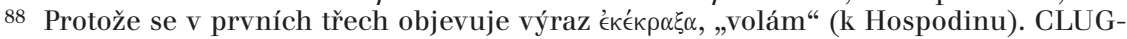
NET, Leon. Dictionnaire grec-française des noms liturgiques en usage dans l'église grecque. London: Variorum Reprints, 1971, s. 80. 
pane, svatý vchod. ${ }^{89}$ Poté za zpěvu starobylého kristologického hymnu Světlo oblažujici ( $\Phi \omega \hat{\varsigma}$ i $\lambda \alpha \rho \grave{\nu}$ ), při kterém se rozžíhala světla v kostele, vejdou a přejdou k hornímu stolci, katedře a následují čtení: Genesis a Př́sloví a ve velkém týdnu Exodus a Job.

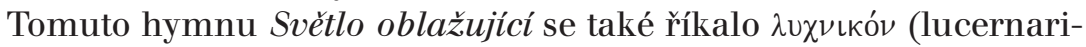
um) a obřad rozžíhání lampy podrobně líčí poutnice Egerie ${ }^{90}$ která jej viděla v Jeruzalémě, když se z jeskyně hrobu Páně vynášelo světlo, které tam neustále hoří a symbolizuje vzkříšeného Krista, který poskytuje spásu všem lidem. Hymnus je rovněž díkůvzdáním za světlo a tvoří centrální část obřadu světla v byzantských nešporách. ${ }^{91}$

S tím jistě souvisí starobylý obřad světla, který se odehrává po prvním čtení z Geneze. Jáhen pronese Přikažte (Povelite, $\kappa \in \lambda \in \cup ́ \sigma \alpha \tau \epsilon)$ ke knězi, který stojí před oltářem a drží v obou rukou svíci a kadidlo a žehná se slovy: Nejvyšši moudrost. Soustřed'me se. Pak se otočí k lidem, žehná je

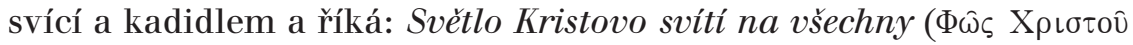

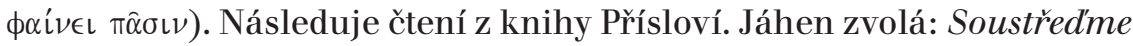
se. Po skončení čtení kněz: Pokoj tobě.

Slovo prikažte vždy bylo prosbou o dovolení k zahájení nějakého obřadu. Někdy se například postačilo uklonit představenému, který udělil požehnání. V jednom rukopisu z 11. století činí arcijáhen arciknězi znamení, aby mu udělil dovolení, a ten mu odpoví znamením křiže. Poté činí znamení křriže i na čtece, aby zahájili trishagion. Jedná se o starobylou výzvu, pocházející z císařského ceremoniálu, kdy ten, kdo hodlal předstoupit před císaře, musel prosit o dovolení tímto zvoláním „přikaž“ (abych mohl předstoupit). ${ }^{92}$

Ve starších rukopisech nikoliv kněz, ale jáhen pronášel Světlo Kristovo svítí na všechny. ${ }^{93} \mathrm{~V}$ jednom slovanském rukopise PPD

89 Jako v liturgii sv. Jana Zalatoústého, Svatá božská liturgie našeho otce svatého Jana Zlatoústého (Schváleno Kongregací pro Východní církve, Rím 15. 7. 2006). Praha, 2007, s. 24.

90 Itinerarium Egeriae. Putováni Egeriino, č. 24, 4.

91 TAFT, Robert F. Život z liturgie. Tradice Východu i Západu, Olomouc: Refugium, 2008, s. 183-191.

92 MRŇÁVEK, Tomáš. Oficiálni verze českého reckokatolického prekladu: Svatá božská liturgie našeho otce svatého Jana Zlatoústého, PROBLEMATIKA PREKLADOV BOHOSLUŽOBNÝCH TEXTOV DO ŽIVÉHO JAZYKA. Súbor štúdií. MARINČÁK, Šimon (ed.), Orientalia et occidentalia, Košice, 2010, s. 118, 126; Vogt, Albert (ed.). Le Livre des cérémonies de Constantin Porphyrogénète, 1. sv. Paris, 1935, s. 66nn.

93 TREMPELAS, Panagiōtēs N. Hai treis leitourgiai, s. 206 v poznámkovém aparátu; SWAINSON, Charles A. The Greek Liturgies Chiefly from Original Authorities. Cambridge, 1884, s. $179 \mathrm{v}$ polovině strany v poznámce pod řeckým textem z 11. století;

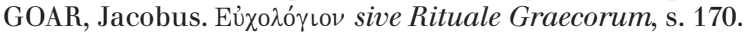


z 15. století je výraz $\kappa \in \lambda \in \cup ́ \sigma \alpha \tau \epsilon$ přeložen jako Vostanite (povstaňte). ${ }^{94}$ Vztahovalo se zřejmě na sedící věřící během čtení, aby povstali k důležitému momentu bohoslužby. Svolávání Kristova světla na všechny přítomné se konalo s otevřenými centrálními svatými dveřmi, kdy všichni poklekli a sklonili hlavu k zemi před světlem. To zřejmě připomíná obřad propouštění katechumenů, kteří se během postní doby připravovali k bezprostřednímu přijetí křtu o Velikonocích ${ }^{95}$ a v tento moment přijímali hořící svíci na znamení pravého světla Krista, které přijmou při křtu a opouštěli bohoslužebné shromáždění. Křest se označoval

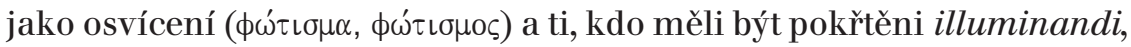
$\phi \omega ́ \tau \iota \zeta o \mu \epsilon \nu o \iota .96$

Po tomto obřadu kněz a sbor zpívá verše ze 140. žalmu. Kněz začíná Má modlitba at' je pred tebou jako kadidlo a pozdvihnuti mých rukou jako obèt večerni a okuřuje oltář. Během tohoto prvního verše všichni klečí. Potom chór, který zpívá, stojí a chór, který poslouchá, klečí. ${ }^{97}$

\section{Litanie - katechumeni, věřící}

Následují prosby a modlitby za katechumeny a věřící, jejichž uspořádání je obdobné jako v běžné liturgii. Po modlitbě nad katechumeny, kteří se nesměli účastnit liturgie věřících pro „nedostatek“ víry, jáhen propouští katechumeny se slovy: Kdo jste katechumeni, odejdète (izidite, проє́ $\lambda \theta \in \tau \epsilon) !$ Katechumeni, odejdéte! Kdo jste katechumeni, odejdète! At' tady nezůstává nikdo z katechumenů... ${ }^{98} \mathrm{Od}$ středy po třetí neděli postní, kdy začínalo v Konstantinopoli období bezprostřední př́ípravy na křest, ${ }^{99}$ jáhen pak přidává další prosby za ty, kteří se bezprostředně připravovali ke křtu se zvoláním - katechumeni odejdète... Kdo se připravujete ke křtu, odejdéte! Kdo se připravujete ke křtu, modlete se k Pánu. ... A my vérící, znovu a znovu v pokoji modleme se $k$ Pánu. ${ }^{100}$ Věřící se modlí za ty, kteří budou pokřtěni o velikonocích, aby jim Pán

\footnotetext{
${ }^{94}$ КРАСНОСЕЛЬЦЕВ, Николай. Сведения о некоторых литургических рукописях ватиканской библиотеки с замечаниями о составе и особенностях богослужебных чинопоследований, в них содержащихся, и с приложениями. Казань, 1885, s. 169.

${ }^{95}$ MRŇÁVEK, Tomáš. Křest v byzantsko-konstantinopolské tradici. Fórum pastorálních teologů VIII. Krest a iniciace. Velehrad-Roma: Refugium, 2011, s. 159-161.

${ }^{96}$ MRÑÁVEK, Tomáš. Křest v byzantsko-konstantinopolské tradici. s. 160-161.

97 CHARRON, Cyrille. Les saintes et divines liturgies, s. 135-136.

98 Svatá božská liturgie, s. 33.

${ }^{99}$ MATEOS, Juan. Le Typicon de la Grande Église, s. 31, 38.

100 CHARRON, Cyrille. Les saintes et divines liturgies, s. 139-140.
} 
dal víru, osvícení, sílu a připočetl je ke svému stádci, církvi. Místo výrazu $\pi \rho \operatorname{c}^{\prime} \lambda \theta \epsilon \tau \epsilon$ se někde objevuje $\pi \rho \sigma^{\prime} \in \lambda \theta \epsilon \tau$, tj. přistupte, ve smyslu, aby katechumené přistoupili pro požehnání, po kterém opustili shromáždění. ${ }^{101}$ Poslední prosba vyprošuje, aby sklonili hlavu k požehnání před propuštěním: Kdo se připravujete ke křtu, skloňte své hlavy před Pánem. ${ }^{102}$

\section{Velký vchod}

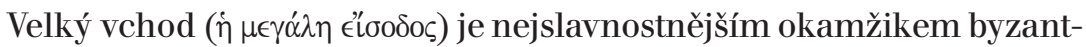
ské liturgie, kdy jsou přenášeny eucharistické dary z žertveniku na oltář. Kněz okuřuje oltár̆, svatyni, kostel, ikonostas a lid jako v liturgii a jáhen jej předchází se svící. Chór pronáší hymnus Nyní nebeské mocnosti spojené s námi neviditelně slouži, protože přicházi Král slávy: tato tajemná a již dovršená obèt je slavnostně prrinášena. ${ }^{103}$ Poté kněz s jáhnem přejdou k žertveniku, kněz okouří dary a odevzdá jáhnovi kadidelnici a jáhnovi dá vozduch na levé rameno jako při liturgii. Kněz pak uchopí diskos do pravé ruky a drží jej na úrovni čela a kalich na úrovni prsou. Nekoncelebrující kněží doprovázejí eucharistii se svícemi. Jáhen jde před knězem a okuřuje. Kněz jde jako při liturgii, ale nic neříká, všichni ostatní klečí. Když vyjde ze svatyně, lid zbožně pronese: Hle vchází král slávy. Lid pak pokračuje: Hle tajemná obét již dovršená a doprovázená: pristupme také my s vírou a strachem, abychom se stali účastnými života véčného. Aleluja. ${ }^{104}$

Velký vchod byl do liturgie uveden pravděpodobně za Petra Fulona v Antiochii, společně s krédem (471) jako protest proti ariánům a makedoniánům. Do byzantské liturgie vstupuje za císaře Justina II. (565-578). Modlitby dosvědčují, že se jedná o dary již posvěcené. Věřící na projev eucharistické úcty vykonávají velkou prostraci. Někde

101 TREMPELAS, Panagiōtēs N. Hai treis leitourgiai, s. 209; podrobný popis propuštění katechumenů a požehnání se nachází v Apoštolských konstitucích ze 4. století: Les Constitutions apostoliques, VIII, 6, 3-11; VIII, 8, 1-6. Introduction, texte critique, traduction et notes par METZGER, M., Sources chrétiennes 336, Paris: Cerf, 1987, s. 152-156, 160.

102 CHARRON, Cyrille. Les saintes et divines liturgies, s. 140.

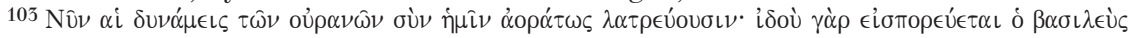

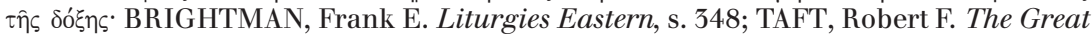
Entrance, s. 55.

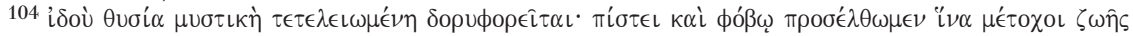
$\alpha i \omega v i ́$ v $\gamma\llcorner\nu \omega ́ \mu \epsilon \theta \alpha$. $\alpha \lambda \lambda \eta \lambda$ oúï $\alpha$. BRIGHTMAN, Frank E. Liturgies Eastern, s. 348; TAFT, Robert F. The Great Entrance, s. 55; CHARRON, Cyrille. Les saintes et divines liturgies, s. $143-144$. 
je zvykem, že si věřící lehají před kněze a ten se jich posvěcenými dary dotýká. ${ }^{105}$ Konstantinopolský patriarcha Eutichius (552-565 a 577-582) ve své homilii106 hovoří o velkém vchodu. Dary, které jsou přinášeny, nazývá „Králem slávy“, i když tyto dary nejsou ještě konsekrované. Dovolává se svědectví sv. Atanáše (Alexandrie), který upozorňuje neofyty, aby se nenechali zmást. Chléb přinášený levity (jáhny) bude konsekrován až po velké modlitbě (anafoře). ${ }^{107} \mathrm{Z}$ této informace lze vyvodit, že se jednalo o egyptský zvyk přinášení darů. ${ }^{108} \mathrm{~S}$ velkou pravděpodobností vychází z liturgie předem posvěcených darů, jak to vyjadřují různé modlitby, především pak: Nyní nebeské mocnosti...

\section{Otče náš}

Po velkém vchodu jáhen pronáší ektenii Naplňme naši večerni modlitbu pred Pánem, která je kromè této první prosby s úpravami převzata z řádné liturgie a nachází se mezi anaforou a modlitbou Otče náš. Modlitba Páně je středem PPD a pravděpodobně to byla jediná modlitba, kterou tato liturgie původně začínala.

\section{Pozdvihování, lámání chleba a přijímání}

Dříve se pozdvihování konalo během modlitby Otčenáš. V současnosti kněz pouze vloží ruku pod vélum, které zahaluje diskos, a dotkne

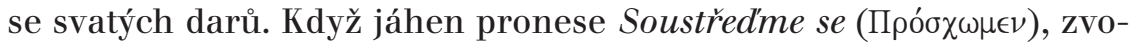
lá: Předem posvěcené svaté (dary) svatým. ${ }^{109}$ Pozdvihování se nemá konat, protože již proběhlo v řádné liturgii. Některé dokumenty nás však informují o tom, že se předem posvěcené dary pozvedaly ${ }^{110}$ nebo o pozdvihování vủbec nehovoří. ${ }^{111}$ Dále liturgie probíhá jako řádná liturgie. Mohou při ní přijímat všichni věřící a tak lze docílit toho, že i při aliturgickém dnu mohou přijmout eucharistického Krista. Podává se samozřejmě pod obojí lžičkou z kalicha, jako při běžné liturgii, ale kněz podává tělo Páně s vínem. S tím do jisté míry souvisí teorie

\footnotetext{
105 TAFT, Robert F. The Great Entrance, s. 7.

106 EUTICHIUS. De paschate e de sacrosancta eucharistia, č. 8. PG 86, 2400-2401.

107 TAFT, Robert F. The Great Entrance, s. 84-85.

108 THIBAUT, J.-B. Origine de la messe, s. 45.

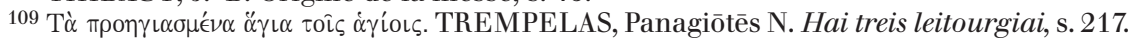

110 BRIGHTMAN, Frank E. Liturgies Eastern, s. 351; GOAR, Jacobus. Eủxo ale Graecorum, s. 172.

111 PARENTI, Stefano - VELKOVSKA, Elena. L'Eucologio Barberini gr. 336, f. 43r, s. 86.
} 
consecratio per commixtionem, která měla na východě své zastánce. Patriarcha Michael Kerularios (1043-1059) tvrdí: „předem posvěcený chléb je vložen do svatého kalichu a víno, které je v něm obsaženo, je proměněno na krev Kristovu“.112

Po přijímání jsou recitovány modlitby díkůvzdání za nebeský chléb a kalich života a za účast na tělu a krvi Kristově. Po liturgii kněz věřícím rozděluje antidor, tj. požehnaný chléb.

\section{Závěrem}

Velkopostní liturgie předem posvěcených darů vždy patřila k duchovnímu dědictví východní a především byzantské liturgické tradice. Určitě i dnes dokáže nabídnout své obohacení všem věřícím, kteří se jí budou účastnit. Rovněž by se zde mohla nalézt cesta k obnovení druhého či bezprostředního katechumenátu východní tradice, který je k této liturgii, jak bylo nastíněno, neodmyslitelně vázán.

\section{ABSTRACT \\ TOMÁŠ MRŇŃVEK \\ Liturgy of the presanctified gifts}

In this article we intend to present the divine liturgy of the presanctified gifts, an ancient and significant Lenten liturgy of the Byzantine tradition. It consists of vespers and a solemn Holy Communion.

\section{Key words}

Liturgy, Lent, presanctified gifts, Holy Communion

$\overline{112}$ ANDRIEU, Michel. Immixtio et consecratio, s. 201-204. 